\title{
SCENTRALIZOWANY MODEL ROZLICZENIA PODATKU OD TOWARÓW I USŁUG JAKO NOWE WYZWANIE DLA JEDNOSTEK SAMORZĄDU TERYTORIALNEGO W 2017 ROKU
}

\section{THE CENTRALIZED MODEL OF SETTLEMENT OF TAX ON GOODS AND SERVICES AS A NEW CHALLENGE FOR LOCAL GOVERNMENT UNITS IN 2017}

\section{Streszczenie}

Dnia 29 września 2015 roku Trybunał Sprawiedliwości Unii Europejskiej wydał wyrok w sprawie C-276/14, EU:C:2015:635 Gmina Wrocław przeciwko Ministrowi Finansów uznając, że podmioty prawa publicznego, takie jak gminne jednostki budżetowe nie mogą być uznane za podatników podatku od wartości dodanej, ponieważ nie spełniają kryterium samodzielności gospodarczej przewidzianej w art. 9 ust. 1 Dyrektywy Rady 2006/112/WE z dnia 28 listopada 2006 r., w sprawie wspólnego systemu podatku od wartości dodanej (Dz.U. UE L 347 z dnia 11 grudnia 2006 r.).

Oznacza to, iż zgodnie z publikowanym wyrokiem samorządowe jednostki budżetowe nie posiadają odrębności podatkowej w podatku od towarów i usług, zatem wszelkie czynności przez nie dokonywane na rzecz osób trzecich powinny być rozliczane przez jednostkę samorządu terytorialnego, która je utworzyła.

Artykuł jest prezentacją nowych zadań, systemowych rozwiązań oraz problemów wynikających z wdrożenia nowego scentralizowanego modelu rozliczania podatku od towarów i usług $\mathrm{w}$ jednostkach samorządu terytorialnego. 
Słowa kluczowe: scentralizowany model rozliczenia; podatek od towarów i usług; jednostki samorządu terytorialnego.

\begin{abstract}
On the $29^{\text {th }}$ September 2015, the European Union's Court of Justice delivered its judgment in Case C-276/14, EU: C: 2015: 635 Municipality of Wroclaw against the Minister of Finance, recognizing that public bodies such as municipal budgetary units cannot be considered as taxpayers of value added tax, because they do not meet the criteria of economic independence as provided for in Article. 9 paragraph. 1 of Council's Directive 2006/112/EC from the $28^{\text {th }}$ November 2006, on the common system of value added tax (Official Journal of the European Union L 347 of the $11^{\text {th }}$ December 2006).

This means that, according to the published ruling, local government's budgetary units do not have a tax distinction on goods and services tax, so all activities performed by them in favour of third parties should be settled by the local government units that created them.

The article is a presentation of new tasks, system solutions and problems arising from the implementation of a new centralized model of goods and services tax settlement in local government units.
\end{abstract}

Keywords: centralized model of settlement; tax on goods and services; local government units.

\title{
1. Wprowadzenie
}

Dnia 29 września 2015 roku Trybunał Sprawiedliwości Unii Europejskiej wydał wyrok w sprawie Gminy Wrocław przeciwko Ministrowi Finansów ${ }^{1}$ uznając, że podmioty prawa publicznego, takie jak gminne jednostki budżetowe nie mogą być uznane za podatników podatku od wartości dodanej, ponieważ nie spełniają kryterium samodzielności gospodarczej przewidzianej w art.9 ust.1 Dyrektywy Rady 2006/112/WE z dnia 28 listopada 2006 r. w sprawie wspólnego systemu podatku od wartości dodanej².

$\mathrm{Z}$ uwagi na to, iż samorządowe jednostki budżetowe nie posiadają odrębności podatkowej w podatku od towarów i usług, wszelkie czynności przez nie dokonywane na rzecz osób trzecich, zgodnie z opublikowanym wyrokiem, a także uchwałą Naczelnego Sądu Administracyjnego z 24 czerwca 2013 r.

Sygnatura C-276/14, EU:C:2015:635 (dalej: Wyrok TSUE, C-276/14).

2 Dz.Urz. UE L 347 z dnia 11 grudnia 2006 r. (dalej: Dyrektywa 2006/112/WE). 
(I FPS 1/13), powinny być rozliczane przez jednostkę samorządu terytorialnego, która je utworzyła. Oznacza to, że przy scentralizowanym modelu rozliczeń, świadczenie jakichkolwiek czynności pomiędzy jednostkami budżetowymi tej samej gminy, stanie się świadczeniem wewnętrznym niepodlegającym w ogóle opodatkowaniu podatkiem od towarów i usług. W związku z czym podatnikami podatku od towarów i usług mogą być wyłącznie: gminy, powiaty lub województwa, obowiązane do wspólnego scentralizowanego rozliczenia podatku od towarów i usług od transakcji realizowanych we wszystkich podległych jednostkach organizacyjnych.

\section{Dotychczasowy status podatkowy jednostek budżetowych}

Przez wiele lat status jednostek budżetowych na gruncie podatku od towarów i usług budził poważne wątpliwości prawne. Zarówno Ministerstwo Finansów jak i sądy administracyjne ${ }^{3}$ prezentowały pogląd, iż jednostki budżetowe mogą być samodzielnymi podatnikami podatku od towarów i usług. W praktyce, dla celów tego podatku istniały dwa tryby rejestracji, odrębnie dla jednostek samorządu terytorialnego oraz ich jednostek budżetowych. Podmioty tego podatku posiadały także odrębne numery identyfikacji podatkowej. Minister Finansów uzasadniał swoje stanowisko tym, że jeżeli wyodrębnione ze struktury gminy jednostki budżetowe prowadzą działalność gospodarczą w sposób samodzielny, oceniany w oparciu o obiektywne kryteria i wykonują czynności podlegające opodatkowaniu podatkiem od towarów i usług, to podmioty te należy uznać za odrębnych od gminy podatników podatku od towarów i usług ${ }^{4}$.

W związku z czym przez ponad 23 lata obowiązywania w Polsce podatku od towarów i usług ${ }^{5}$ jednostki oraz zakłady budżetowe były traktowane jako odrębni od swoich jednostek macierzystych podatnicy, którzy w oparciu o zawarte umowy cywilnoprawne wykonywali czynności opodatkowane podatkiem od towarów i usług. Jednostki te mogły skorzystać ze zwolnienia podmiotowego w podatku od towarów i usług, jeśli wartość sprzedaży nie przekroczyła

3 Wyrok Wojewódzkiego Sądu Administracyjnego z dnia 21 listopada 2011 r., I SA/Wr 989/12, CBOSA oraz WSA w Gorzowie Wielkopolskim z dnia 14 sierpnia 2009 r., I SA/Go 290/09.

4 Postanowienie Naczelnego Sądu Administracyjnego z dnia 30 stycznia 2013 r., I FSK 311/12, CBOSA.

5 Podatek ten został wprowadzony ustawą z dnia 8 stycznia 1993 r. o podatku od towarów i usług oraz o podatku akcyzowym (Dz.U. z 1993 r. Nr 11, poz. 50 ze zm.). 
u nich łącznie w poprzednim roku podatkowym kwoty: $150000 \mathrm{zł}^{6}$. Większość jednostek organizacyjnych, z uwagi na niskie obroty, korzystała z tego uprawnienia, natomiast niektóre jednostki organizacyjne gmin, powiatów, województw dokonywały rejestracji jako odrębni podatnicy podatku od towarów i usług. Podmioty te zobligowane były do samodzielnego rozliczania podatku od towarów i usług ze swojej działalności oraz do składania stosownych deklaracji i ponoszenia odpowiedzialności karnoskarbowej za ewentualne błędy w rozliczeniach.

\section{Realizacja zadań publicznych $\mathrm{w}$ aspekcie opodatkowania podatkiem od towarów i usług}

Dokonując rozważań na temat scentralizowanego modelu rozliczeń podatku od towarów i usług na przykładzie podstawowej jednostki samorządu terytorialnego należy mieć na uwadze nie tylko specyfikę rozliczeń tego podatku ale przede wszystkim normy prawne regulujące tę problematykę i analizę prawną gminy w zestawieniu $\mathrm{z}$ konstytucyjną i ustawową pozycją gminy.

Zgodnie z art.164 ust.1 Konstytucji Rzeczypospolitej Polskiej z 2 kwietnia $1997 \mathrm{roku}^{7}$, gmina jest podstawową jednostką samorządu terytorialnego. Podstawy prawne funkcjonowania gminy jako jednostki samorządu terytorialnego zostały również unormowane w Europejskiej Karcie Samorządu Lokalnego ${ }^{8}$ oraz w ustawie z dnia 8 marca 1990 roku o samorządzie gminnym ${ }^{9}$, a także w licznych ustawach i aktach wykonawczych związanych z jednostkami samorządu terytorialnego. W myśl art. 16 ust. 2 oraz art. 163 Konstytucji RP oraz art. 2 ust. 1 u.s.g., zarówno gmina jak i pozostałe wspólnoty samorządowe uczestniczą w sprawowaniu władzy publicznej, wykonując w imieniu własnym

$6 \quad$ Art. 113 ust. 1 ustawy z dnia 11 marca 2004 r. o podatku od towarów i usług (tekst jedn. Dz.U. z 2016 r., poz. 710 ze zm.).

7 Dz.U. z 1997 r. Nr 78, poz. 483 ze zm. (dalej: Konstytucja RP).

8 Akt ten został sporządzony w dniu 15 października 1985 roku w Strasburgu w ramach działalności Rady Europy. Karta weszła w życie 1 września 1988 roku i została ratyfikowana przez Polskę w 1993 roku. Karta, zgodnie z brzmieniem art. 241 ust. 1 Konstytucji RP ma rangę ,uprzywilejowanej” umowy międzynarodowej, z której treścią powinny być zgodne wszystkie ustawy krajowe.

9 Tekst jedn. Dz.U. z 2015 r., poz. 1515 ze zm. Ustawa ta pierwotnie nosiła tytuł ustawy o samorządzie terytorialnym, zmieniony w ramach reformy administracji publicznej w 1998 roku wraz z powołaniem innych niż gmina jednostek samorządu terytorialnego (dalej: u.s.g.). 
i na własną odpowiedzialność istotną część zadań publicznych nie zastrzeżonych przez Konstytucję lub ustawy dla organów innych władz publicznych. Natomiast na mocy art.164 ust.3 Konstytucji RP, gmina wykonuje wszystkie zadania samorządu terytorialnego nie zastrzeżone dla innych jednostek samorządu terytorialnego.

Gmina posiada osobowość prawną ${ }^{10}$, przysługują jej prawo własności i inne prawa majątkowe, a gwarantem jej samodzielności jest ochrona sądowa (art. 165 Konstytucji RP). Antycypacja przepisów konstytucyjnych znajduje się w art. 2 u.s.g., gdzie sprecyzowano, iż gmina wykonuje zadania publiczne w imieniu własnym i na własną odpowiedzialność, posiada osobowość prawną a jej samodzielność podlega ochronie sądowej.

Zgodnie $\mathrm{z}$ art. 166 Konstytucji RP, gmina wykonuje zadania publiczne służące zaspokajaniu potrzeb wspólnoty samorządowej jako zadania własne. Doprecyzowanie zakresu zadań publicznych gminy znajduje się w art. 6 ust. 1 u.s.g., zgodnie z którym do zakresu działania gminy należą wszystkie sprawy publiczne o znaczeniu lokalnym, pod warunkiem, że nie zostały zastrzeżone dla innych podmiotów. Uszczegółowienie tych zadań publicznych znajduje się w art. 7 ust.1 u.s.g., który zawiera definicję zadań własnych gminy rozumianą jako zaspokajanie zbiorowych potrzeb wspólnoty oraz przedmiotowy katalog zadań własnych gminy ${ }^{11}$.

Ustawa zasadnicza w art. 166 ust. 1 i 2 wyróżnia dwa rodzaje zadań publicznych wykonywanych przez samorządy terytorialne: zadania własne oraz zadania zlecone. Zadania publiczne służące zaspokajaniu potrzeb wspólnoty samorządowej są wykonywane przez gminę jako zadania własne, natomiast zadania zlecone, realizowane są na podstawie określonych ustaw, w przypadku uzasadnionych potrzeb państwa. Podział zadań gminy na własne i zlecone ma konsekwencje prawne w sposobie określania zadań, sposobie finansowania i nadzoru nad ich realizacją ${ }^{12}$.

10 Osobowość prawna gminy oznacza, że staje się ona nie tylko podmiotem prawa publicznego ale również prawa prywatnego. Dzięki temu jednostka ta może posiadać majątek, samodzielnie nim rozporządzać, zarządzać, zaciągać zobowiązania i występować jako pełnoprawny uczestnik obrotu cywilnoprawnego. W. Kisiel, Komentarz do art. 2, [w:] K. Bandarzewski, P. Chmielnicki, Ustawa o samorzqdzie gminnym. Komentarz, Warszawa 2013. s. 63-64.

11 Wykaz ten nie jest wyczerpujący o czym świadczy zwrot w „szczególności”. K. Byjoch, J. Sulimierski, J.P. Tarno, Samorzqd terytorialny po reformie ustrojowej państwa, Warszawa 2000, s. 30.

12 E. Nowacka, Samorzad terytorialny w ustroju państwowym, Warszawa 2003, s. 79. 
Zadania własne w myśl u.s.g., charakteryzują się tym, że są realizowane przez gminę samodzielnie, we własnym imieniu, na własną odpowiedzialność i są finansowane z budżetu gminy. Natomiast zadania zlecone należą do administracji rządowej i są przekazywane gminie do wykonania po zapewnieniu odpowiednich środków finansowych w postaci dotacji z budżetu państwa ${ }^{13}$. Zlecanie podstawowym jednostkom samorządu terytorialnego zadań z zakresu administracji rządowej może być realizowane na podstawie ustawy lub w drodze porozumienia ${ }^{14}$. Przy realizacji tego typu zadań nie obowiązuje zasada, że gminy wykonują zadania publiczne w imieniu własnym i na własną odpowiedzialność przy pomocy własnych organów i jednostek organizacyjnych. Zadania zlecone różnią się od zadań własnych na kilku płaszczyznach. Są zazwyczaj ściśle sparametryzowane pod względem celów, rezultatów i sposobów ich realizacji ${ }^{15}$. Inny jest też organ odwoławczy w sprawach indywidualnych, szerszy zakres uprawnień nadzorczych i jak już wcześniej wzmiankowano, odmienne zasady finansowania ${ }^{16}$.

Zadania własne gminy zamykają się $\mathrm{w}$ czterech podstawowych kategoriach związanych z infrastrukturą: techniczną, społeczną, porządkiem i bezpieczeństwem publicznym oraz ładem przestrzennym i ekologicznym. Zamieszczony w art.7 u.s.g. katalog zadań własnych gminy nie ma charakteru zamkniętego i może być uzupełniany innymi dodatkowymi zadaniami nie naruszającymi właściwości innych podmiotów ${ }^{17}$.

\subsection{Jednostki budżetowe gminy}

W celu wykonywania zadań, zarówno własnych, jak i zleconych, zgodnie z art. 9 ust. 1 u.s.g., podstawowa jednostka samorządu terytorialnego może

13 Na podstawie art. 49 ust. 1 ustawy z dnia 13 listopada 2003 r. o dochodach jednostek samorządu terytorialnego, jednostka samorządu terytorialnego wykonująca zadania zlecone z zakresu administracji rządowej oraz inne zadania zlecone ustawami otrzymuje $\mathrm{z}$ budżetu państwa dotacje celowe w wysokości zapewniającej realizację tych zadań (tekst jedn. Dz.U. z 2015 r., poz. 513 ze zm.).

14 H. Izdebski, M. Kulesza, Administracja publiczna: zagadnienia ogólne, Warszawa 2004, s. 254.

15 J. Bober i in., Narastajace dysfunkcje, zasadnicze dylematy, konieczne działania: raport o stanie samorzadności terytorialnej w Polsce, Kraków 2013, s. 22.

16 H. Izdebski, M. Kulesza, Administracja publiczna: zagadnienia ogólne, Warszawa 1999, s. 195.

17 Z. Bukowski, T. Jędrzejewski, P. Rączka, Ustrój samorządu terytorialnego, Toruń 2011, s. $75-76$. 
tworzyć, zarówno jednostki organizacyjne mające osobowość prawną, jak i pozbawione osobowości prawnej, a także zawierać umowy z innymi podmiotami, w tym z organizacjami pozarządowymi. Utworzenie jednostek organizacyjnych ma charakter fakultatywny. Co do zasady jednostki organizacyjne powinny być tworzone jedynie w celu realizacji określonych zadań. W przypadku zrealizowania zadań bądź niemożności ich wykonania, należy daną jednostkę zlikwidować lub przeorganizować ${ }^{18}$. Niektóre rodzaje jednostek organizacyjnych wynikają bezpośrednio z przepisów prawa i tworzone są w gminach obowiązkowo, są to: biblioteki gminne ${ }^{19} \mathrm{i}$ gminne ośrodki pomocy społecznej ${ }^{20}$. W gminie występują też szczególne typy jednostek organizacyjnych do których zaliczyć należy: gminne zawodowe straże pożarne ${ }^{21}$ oraz straże gminne, których celem jest ochrona spokoju i porządku publicznego na terenie gminy ${ }^{22}$. Ponadto szczególną kategorię samorządowych jednostek organizacyjnych stanowią samorządowe osoby prawne, do których zaliczyć można gminne ośrodki kultury ${ }^{23}$.

Kategorią samorządowych osób prawnych są jednoosobowe spółki gmin, które powstały przede wszystkim w wyniku przekształcenia w nie przedsiębiorstw komunalnych na podstawie przepisów obowiązujących przed wejściem w życie ustawy z dnia 20 grudnia 1996 r. o gospodarce komunalnej ${ }^{24}$. Samorządowe osoby prawne stanowią odrębne od właściwych jednostek samorządu terytorialnego podmioty własności samorządowej, w związku z czym jednostka samorządu nie ponosi odpowiedzialności za zobowiązania jej osoby prawnej ${ }^{25}$.

Pojęcie jednostek organizacyjnych niemających osobowości prawnej nie zostało zdefiniowane $\mathrm{w}$ systemie prawa. Wobec czego należy w tym zakresie uwzględnić regulacje zwarte w ustawie z dnia 27 sierpnia 2009 r. o finansach

18 K. Bandarzewski, Komentarz do art. 9, [w:] K. Bandarzewski, P. Chmielnicki, Ustawa o samorządzie gminnym..., s. 184.

19 Art. 8 ust. 2 pkt 2 ustawy z dnia 27 czerwca 1997 r. o bibliotekach (tekst jedn. Dz.U. z 2012 r., poz. 642 ze zm.).

20 Art. 110 ust. 1 ustawy z dnia 12 marca 2004 r. o pomocy społecznej (tekst jedn. Dz.U. z 2016 r., poz. 930 ze zm.).

21 Art. 15 pkt 4 ustawy z dnia 24 sierpnia 1991 r. o ochronie przeciwpożarowej (tekst jedn. Dz.U. z 2016 r., poz. 191 ze zm.).

22 Art.6 ust.1 ustawy z dnia 29 sierpnia 1997 r. o strażach gminnych (tekst jedn. Dz.U. z 2016 r., poz. 706).

23 Art. 9 ust. 1 i 2 ustawy z dnia 25 października 1991 r. o organizowaniu i prowadzeniu działalności kulturalnej (tekst jedn. Dz.U. z 2012 r., poz. 406 ze zm.).

24 Tekst jedn. Dz.U z 2011 r. Nr 45, poz. 236 ze zm.

25 H. Izdebski, Samorząd terytorialny: podstawy ustroju i działalności, Warszawa 2008, s. $196-197$ 
publicznych ${ }^{26}$. Na mocy art. 9 tej ustawy, sektor finansów publicznych tworzą m.in.: organy władzy publicznej, w tym organy administracji rządowej, organy kontroli państwowej i ochrony prawa oraz sądy i trybunały; jednostki samorządu terytorialnego oraz ich związki; jednostki budżetowe i samorządowe zakłady budżetowe.

Zgodnie z art.11 ust. 1 i 2 u.f.p., jednostkami budżetowymi są jednostki organizacyjne sektora finansów publicznych nieposiadające osobowości prawnej, które pokrywają swoje wydatki bezpośrednio z budżetu, a pobrane dochody odprowadzają na rachunek odpowiednio dochodów budżetu państwa albo budżetu jednostki samorządu terytorialnego. Jednostka budżetowa działa na podstawie statutu określającego w szczególności jej nazwę, siedzibę i przedmiot działalności, natomiast podstawę gospodarki finansowej, stanowi plan dochodów i wydatków, nazywany ,planem finansowym jednostki budżetowej”.

Jednostki budżetowe poddane są ostrym rygorom w zakresie wydatkowania środków budżetowych i mogą dokonywać wydatków tylko do wysokości zakreślonej dla nich w obowiązującym budżecie. Dokonywanie większych wydatków niż przewidziane w budżecie lub zaciąganie przez jednostkę budżetową zobowiązania nie znajdującego pokrycia w planie finansowym wydatków tej jednostki stanowi naruszenie dyscypliny finansów publicznych ${ }^{27}$.

Jak wynika z art. 12 ust. 1 pkt 2 i ust. 2 u.f.p. kompetencje do tworzenia, łączenia i likwidowania gminnych, powiatowych lub wojewódzkich jednostek budżetowych, z zastrzeżeniem odrębnych ustaw, posiadają organy stanowiące ${ }^{28}$ jednostek samorządu terytorialnego. Tworząc jednostkę budżetową, organy te nadają jej statut, chyba że odrębne ustawy stanowią inaczej, oraz określają mienie przekazywane tej jednostce w zarząd.

\subsection{Zakłady budżetowe}

Wśród podmiotów, które tworzą sektor finansów publicznych między innymi, obok jednostek budżetowych, zostały wymienione także samorządowe

26 Tekst jedn. Dz.U. z 2016 r., poz. 1870, ze zm. (dalej: u.f.p.).

27 A. Borodo, Finanse publiczne Rzeczypospolitej Polskiej. Zagadnienia prawne, Bydgoszcz 2000, s. 201.

28 Zgodnie $\mathrm{z}$ art. 15 ust.1 u.s.g. organem stanowiącym i kontrolnym $\mathrm{w}$ gminie jest rada gminy oraz odpowiednio w: powiecie - na mocy art. 9 ust. 1 ustawy z dnia 5 czerwca 1998 r. o samorządzie powiatowym (tekst jedn. Dz.U. z 2016 r., poz. 814) - rada powiatu oraz województwie - na podstawie art. 16 ust. 1 ustawy z dnia 5 czerwca 1998 r. o samorządzie województwa (tekst jedn. Dz.U. z 2016 r., poz. 486) - sejmik województwa. 
zakłady budżetowe, które zgodnie z art. 14 u.f.p. mogą realizować zadania własne jednostki samorządu terytorialnego. Zakres tych zadań został jednak ograniczony jedynie do dziewięciu zadań w zakresie: gospodarki mieszkaniowej i gospodarowania lokalami użytkowymi; dróg, ulic, mostów, placów oraz organizacji ruchu drogowego; wodociągów i zaopatrzenia w wodę, kanalizacji, usuwania i oczyszczania ścieków komunalnych, utrzymania czystości i porządku oraz urządzeń sanitarnych, wysypisk i unieszkodliwiania odpadów komunalnych, zaopatrzenia w energię elektryczną i cieplną oraz gaz; lokalnego transportu zbiorowego; targowisk i hal targowych; zieleni gminnej i zadrzewień; kultury fizycznej i sportu, w tym utrzymywania terenów rekreacyjnych i urządzeń sportowych; pomocy społecznej, reintegracji zawodowej i społecznej oraz rehabilitacji zawodowej i społecznej osób niepełnosprawnych; utrzymywania różnych gatunków egzotycznych i krajowych zwierząt, w tym w szczególności prowadzenia hodowli zwierząt zagrożonych wyginięciem, w celu ich ochrony poza miejscem naturalnego występowania; cmentarzy.

Analogicznie, jak ma to miejsce w przypadku jednostek budżetowych, zakład budżetowy na mocy art. 16 ust. 1 i 2 u.f.p. jest tworzony, łączony, przekształcany w inną formę organizacyjno-prawną oraz likwidowany przez organ stanowiący jednostki samorządu terytorialnego. Organ ten tworząc samorządowy zakład budżetowy określa: nazwę i siedzibę zakładu; przedmiot jego działalności; źródła przychodów własnych zakładu; stan wyposażenia zakładu w środki obrotowe oraz składniki majątkowe przekazane zakładowi w użytkowanie; terminy i sposób ustalania zaliczkowych wpłat nadwyżki środków obrotowych dokonywanych przez zakład do budżetu jednostki samorządu terytorialnego oraz sposób i terminy rocznych rozliczeń i dokonywania wpłat do budżetu.

W literaturze przedmiotu stwierdza się, że samorządowy zakład budżetowy stanowi pod względem organizacyjnym i finansowym odrębną jednostkę sektora finansów publicznych niemającą osobowości prawnej ${ }^{29}$. Oznacza to, że w odróżnieniu od jednostki budżetowej, może pokrywać swoje wydatki z uzyskiwanych dochodów, a pewną część wygospodarowanych środków finansowych ma prawo zatrzymać na rok następny ${ }^{30}$.

Na mocy art. 18 ust. 2 pkt 9h u.s.g. uprawnienie do tworzenia, likwidacji i reorganizacji przedsiębiorstw, zakładów i innych gminnych jednostek organizacyjnych oraz wyposażania ich w majątek, przypada radzie gminy. Natomiast

29 Z. Ofiarski, Prawo finansowe, Warszawa 2010, s. 75.

30 S. Owsiak, Finanse publiczne: teoria i praktyka, Warszawa 2001, s. 327. 
wójt gminy, zgodnie z art. 30 ust. 2 pkt 5 u.s.g. ma prawo zatrudniać i zwalniać kierowników gminnych jednostek organizacyjnych. Kierownicy jednostek organizacyjnych gminy nieposiadających osobowości prawnej działają jednoosobowo na podstawie pełnomocnictwa udzielonego przez wójta (art. 47 ust. 1 u.s.g.).

\subsection{Specyfika rozliczenia podatku od towarów i usług w gminie}

Rozpatrując funkcjonowanie gminy jako podstawowej jednostki samorządu terytorialnego $\mathrm{w}$ aspekcie opodatkowania podatkiem od towarów i usług należy zaakcentować, że stosownie do przepisu art. 15 ust. 1 ustawy z dnia 11 marca 2004 r. o podatku od towarów i usług ${ }^{31}$ podatnikami są osoby prawne, jednostki organizacyjne niemające osobowości prawnej oraz osoby fizyczne, wykonujące samodzielnie działalność gospodarczą ${ }^{32}$, bez względu na cel lub rezultat takiej działalności. Gmina podczas realizacji zadań własnych lub zleconych wykonuje zarówno czynności niespełniające definicji działalności gospodarczej, jak i czynności wypełniające te kryteria. W związku z czym ze wskazanej konstrukcji prawnej jednoznacznie wynika, że podstawowa jednostka samorządu terytorialnego wykonując we własnym imieniu i na własny rachunek czynności spełniające definicję działalności gospodarczej, działa w charakterze podatnika podatku od towarów i usług.

Jednakże, zgodnie z art. 15 ust. 6 u.p.t.u. nie uznaje się za podatnika organów władzy publicznej oraz urzędów obsługujących te organy w zakresie realizowanych zadań nałożonych odrębnymi przepisami prawa, dla realizacji których zostały one powołane, z wyłączeniem czynności wykonywanych na podstawie zawartych umów cywilnoprawnych.

Oznacza to, że organ zostanie uznany za podatnika podatku od towarów i usług w dwóch przypadkach. W sytuacji gdy wykonuje czynności inne niż te, które mieszczą się w ramach jego zadań oraz gdy wykonuje czynności mieszczące się w ramach jego zadań, ale czyni to na podstawie umów cywilnoprawny $\mathrm{ch}^{33}$.

31 Dz.U. z 2011 r., Nr 177, poz. 1054, ze zm. (dalej: u.p.t.u.).

32 Zgodnie $\mathrm{z}$ art. 15 ust. 2 u.p.t.u. działalność gospodarcza obejmuje wszelką działalność producentów, handlowców lub usługodawców, w tym podmiotów pozyskujących zasoby naturalne oraz rolników, a także działalność osób wykonujących wolne zawody. Działalność gospodarcza obejmuje w szczególności czynności polegające na wykorzystywaniu towarów lub wartości niematerialnych i prawnych w sposób ciągły dla celów zarobkowych.

33 Umowy w polskim prawie cywilnym zostały uregulowane w księdze trzeciej nazwanej „Prawo zobowiązań” ustawy z dnia 23 kwietnia 1964 r. Kodeks cywilny (tekst jedn. Dz.U. 
Niemniej jednak, mając na uwadze treść przepisów $\S 13$ ust. 1 pkt 12 i pkt 13 rozporządzenia Ministra Finansów z dnia 4 kwietnia 2011 r. w sprawie wykonania niektórych przepisów ustawy o podatku od towarów i usług ${ }^{34}$, czynności związane z wykonywaniem zadań publicznych nałożonych odrębnymi przepisami, wykonywane w imieniu własnym i na własną odpowiedzialność przez jednostki samorządu terytorialnego podlegają zwolnieniu z tego podatku, z wyłączeniem czynności wykonywanych na podstawie zawartych umów cywilnoprawnych. Zwolnieniu podlegają także usługi świadczone pomiędzy: jednostkami budżetowymi; samorządowymi zakładami budżetowymi; jednostkami budżetowymi i samorządowymi zakładami budżetowymi, z wyjątkiem usług wymienionych w poz. 140-153, 174 i 175 załącznika nr 3 do u.p.t.u. oraz usług komunikacji miejskiej.

Z przytoczonych przepisów jednoznacznie wynika, że jednostki samorządu terytorialnego są podatnikami podatku od towarów i usług w zakresie wszelkich czynności, które mają charakter cywilnoprawny, tzn. są przez nie wykonywane na podstawie umów cywilnoprawnych w związku z realizacją zadań publicznych. Będą to zatem wszystkie wykonywane przez te jednostki czynności mieszczące się w sferze ich aktywności cywilnoprawnej, np. czynności sprzedaży, zamiany, wynajmu, dzierżawy.

Powyższe uregulowania są zbieżne z przepisami prawa wspólnotowego. Zgodnie z art. 9 obowiązującej od dnia 1 stycznia 2007 r. Dyrektywy 2006/112/ WE podatnikiem jest każda osoba prowadząca samodzielnie w dowolnym miejscu jakąkolwiek działalność gospodarczą, bez względu na cel czy też rezultaty takiej działalności. Za działalność gospodarczą uznaje się w szczególności wykorzystywanie, w sposób ciągły, majątku rzeczowego lub wartości niematerialnych w celu uzyskania $\mathrm{z}$ tego tytułu dochodu.

Na mocy art. 13 Dyrektywy 2006/112/WE krajowe, regionalne i lokalne organy władzy oraz inne podmioty prawa publicznego nie są uważane za podatników w związku z działalnością, którą podejmują lub transakcjami, których dokonują jako organy władzy publicznej, nawet jeśli pobierają należności, opłaty, składki lub płatności w związku z takimi działaniami lub transakcjami. Jednak w przypadku, gdy podejmują takie działania lub dokonują takich transakcji, są uważane za podatników w odniesieniu do tych działań lub transakcji,

z 2017 r., poz. 459 ze zm.).

34 Dz.U. z 2013 r., poz. 247 ze zm. 
gdyby wykluczenie ich z kategorii podatników prowadziło do znaczących zakłóceń konkurencji.

Na przestrzeni wielu lat istniały także duże wątpliwości i spory interpretacyjne w odniesieniu do statusu urzędu gminy. Problemową kwestią było zaliczenie urzędu gminy do kategorii jednostki organizacyjnej gminy, a także przyznania mu rangi podatnika podatku od towarów i usług. $Z$ treści art. 33 ust. 1 u.s.g., który stanowi, że wójt (burmistrz, prezydent miasta) wykonuje zadania przy pomocy urzędu gminy (miasta), wynika, że urząd gminy stanowi wyłącznie aparat pomocniczy gminy. Jednostkę zapewniającą obsługę administracyjną, organizacyjną i techniczną wójta. Jest to struktura, której jedynym celem jest zapewnienie sprawnej realizacji zadań organu gminy. Skoro nie jest to jednostka organizacyjna gminy, gdyż urzędu gminy nie tworzy gmina, to nie ma podstaw, by przyjąć, że urząd gminy jest jednostką budżetową w rozumieniu art. 20 ust. 1 u.f.p., która winna funkcjonować w oparciu o swój statut ${ }^{35}$.

Obecnie zarówno w orzecznictwie oraz doktrynie dominuje pogląd, iż stosownie do treści art. 2 ust. 1 u.s.g. w związku z art. 15 ust. 1 u.p.t.u., to właśnie gmina - jako osoba prawna wykonująca zadania publiczne w imieniu własnym i na własną odpowiedzialność $\mathrm{z}$ tytułu realizacji czynności określonych $\mathrm{w}$ art. 5 ust. 1 u.p.t.u. - jest podatnikiem podatku od towarów i usług, nie zaś jej urząd $^{36}$.

Swoistą cechą determinującą status podatnika podatku od towarów i usług jest pełna samodzielność w wykonywaniu działalności gospodarczej. Kryterium samodzielności gospodarczej to przede wszystkim brak jakiegokolwiek hierarchicznego podporządkowania, posiadanie własnego majątku oraz możliwość podejmowania decyzji we własnym imieniu i na własny rachunek, a zarazem posiadanie odpowiedniego stopnia odpowiedzialności za podjęte decyzje,

35 Wyrok WSA w Krakowie z dnia 20 października 2009 r., I SA/Kr 1078/09, CBOSA.

36 Wyrok NSA z dnia 10 listopada 1999 r., I SA/Wr 1697/99, „Orzecznictwo Naczelnego Sądu Administracyjnego" 2001, nr 2, poz. 68; wyrok WSA w Opolu z dnia 8 czerwca 2005 r., I SA/Op 79/05, CBOSA, wyrok WSA we Wrocławiu z dnia 22 marca 2007 r., I SA/Wr 852/06, CBOSA; wyrok WSA w Lublinie z dnia 9 lipca 2008 r., I SA/Lu 167/08, CBOSA oraz interpretacje indywidualne dyrektorów izb skarbowych: w Warszawie z dnia 9 kwietnia 2008 r., IPPP1-443-157/08-2/IŻ oraz z dnia 28 maja 2008 r., IPPP1-443-549/08-4/AK; w Bydgoszczy z dnia 26 czerwca 2008 r., ITPP1/443-375/08/ MS; w Katowicach z dnia 10 października 2007 r. oraz w Poznaniu z dnia 2 czerwca 2008 r., ILPP1/443-277/08-2/HW; J. Zubrzycki, Leksykon VAT 2014, t. 1, Wrocław 2014, s. 881. 
w tym za szkody poniesione wobec osób trzecich, jak również ponoszenie przez podmiot ryzyka gospodarczego ${ }^{37}$.

\section{Centralizacja rozliczeń podatku od towarów i usług gminy i jej jednostek budżetowych w świetle wyroku TSUE nr C-276/14}

Gmina Wrocław miała w tym zakresie istotne wątpliwości i stała na stanowisku, że gminne jednostki organizacyjne nie spełniają kryterium samodzielności ${ }^{38}$, w związku z czym nie mogą być uznane za odrębnych od gminy podatników podatku od towarów i usług. Pogląd ten podzielił również NSA. W uchwale z 24 czerwca 2013 r. sygn. akt I FPS 1/13 skład siedmiu sędziów uznał, że jednostki budżetowe nie prowadzą samodzielnej działalności gospodarczej i tym samym nie spełniają kryterium bycia podatnikiem, zgodnie z przepisami u.p.t.u. oraz Dyrektywy 2006/112/WE, gdyż tylko gmina jako podstawowa jednostka samorządu terytorialnego ma osobowość prawną i przysługuje jej prawo własności i inne prawa majątkowe, podczas gdy gminna jednostka budżetowa stanowi jednostkę organizacyjną niemającą osobowości prawnej. O utworzeniu, zakresie kompetencji, połączeniu lub likwidacji takiej jednostki decyduje gmina. Gminna jednostka budżetowa nie ma własnego mienia, natomiast zarządza pewną częścią majątku gminy, która została jej przez tę gminę powierzona. Wszelka działalność mogąca podlegać podatkowi od towarów i usług jest wykonywana w imieniu i na rachunek gminy w ramach limitu środków przyznanych jednostce przez gminę w uchwale budżetowej na dany rok. Ponadto wydatki takiej jednostki są pokrywane bezpośrednio z budżetu gminy, a dochody są wpłacane na rachunek gminy. W aspekcie finansowym nie ma zatem związku pomiędzy wynikiem finansowym wypracowanym w ramach działalności gospodarczej wykonywanej przez gminną jednostkę budżetową a poniesionymi przez nią wydatkami, ani w konsekwencji, ryzyka finansowego związanego z opodatkowanymi czynnościami. Wielkość wydatków gminnej jednostki budżetowej nie jest zatem związana z kwotą osiągniętych przez nią

37 Wyrok WSA w Poznaniu z dnia 5 marca 2012 r., I SA/Po 791/11, CBOSA.

38 Gminne jednostki budżetowe mają ograniczony zakres swobody w obrocie gospodarczym (zawierając umowy cywilnoprawne występują jako pełnomocnicy gminy); nie uzyskują przychodów (pobrane dochody odprowadzają do budżetu gminy) i nie ponoszą kosztów (wydatki pokrywają bezpośrednio z budżetu gminy). Nie posiadają własnego majątku (jednostki te dysponują jedynie mieniem przekazanym im w zarząd przez gminę); nie ponoszą ryzyka gospodarczego oraz odpowiedzialności wobec osób trzecich. 
dochodów, którymi nie może ona zresztą dysponować. Co więcej, jednostka budżetowa nie odpowiada też za szkody wyrządzone swoją działalnością, odpowiedzialność tę ponosi wyłącznie gmina.

Niezależnie od rozstrzygnięcia podjętego w uchwale, zwykły skład NSA powziął wątpliwość i zwrócił się do Trybunału Sprawiedliwości Unii Europejskiej z pytaniem prejudycjalnym dotyczącym wykładni przepisów prawa unijnego, czy w świetle art. 4 ust. 2 w związku z art. 5 ust. 3 Traktatu o Unii Europejskiej ${ }^{39}$ jednostka organizacyjna gminy może być uznana za podatnika podatku od towarów i usług w sytuacji, gdy wykonuje czynności w charakterze innym niż organ władzy publicznej w rozumieniu art. 13 Dyrektywy 2006/112/ WE, pomimo, że nie spełnia warunku samodzielności przewidzianego $\mathrm{w}$ art. 9 ust. 1 tej dyrektywy ${ }^{40}$.

TSUE udzielając odpowiedzi ${ }^{41}$ stwierdził, że aby podmiot prawa publicznego mógł zostać uznany za podatnika w rozumieniu Dyrektywy 2006/112/ WE, zgodnie z jej art. 9 ust. 1 powinien on samodzielnie prowadzić działalność gospodarczą (pkt 30). Z orzecznictwa Trybunału wynika, że w celu ustalenia, czy taka jednostka prowadzi działalność gospodarczą samodzielnie, należy zbadać, czy w ramach prowadzenia tej działalności jest ona podporządkowana gminie, do której należy (pkt 33).

Jednostki budżetowe będące przedmiotem postępowania głównego wykonują działalność gospodarczą powierzoną im w imieniu i na rachunek gminy oraz nie odpowiadają one za szkody spowodowane tą działalnością, ponieważ odpowiedzialność tę ponosi wyłącznie gmina (pkt 37). Owe jednostki nie ponoszą ryzyka gospodarczego związanego z rzeczoną działalnością, ponieważ nie dysponują własnym majątkiem, nie osiągają własnych dochodów i nie ponoszą kosztów dotyczących takiej działalności, bowiem uzyskane dochody są wpłacane do budżetu gminy a wydatki są pokrywane bezpośrednio z tego budżetu (pkt 38).

A zatem podmioty prawa publicznego, takie jak gminne jednostki budżetowe nie mogą być uznane za podatników podatku od wartości dodanej, ponieważ nie spełniają kryterium samodzielności gospodarczej przewidzianego w tym przepisie.

Zgodnie z uchwałą z dnia 26 października 2015 r. sygn. akt I FPS 4/15 Naczelnego Sądu Administracyjnego także samorządowy zakład budżetowy,

39 Wersja skonsolidowana Dz.Urz. UE z 2012 r., C 326, s. 13 i n.

40 Postanowienie NSA z dnia 10 grudnia 2013 r., I FSK 311/12, CBOSA.

41 Wyrok TSUE, C-276/14. 
pomimo większego niż jednostki budżetowe stopnia samodzielności, nie może być traktowany jako odrębny podatnik podatku od towarów i usług, od jednostki samorządu terytorialnego, która go utworzyła, gdyż nie jest on wystarczająco samodzielny.

A zatem następstwem wyroku TSUE nr C-276/14 oraz uchwały NSA z dnia 24 czerwca 2013 r., sygn. akt I FPS 1/13 jest uznanie, że samorządowe jednostki budżetowe i samorządowe zakłady budżetowe nie mają odrębności podatkowej w zakresie podatku od towarów i usług, więc wszelkie czynności przez nie dokonywane na rzecz osób trzecich powinny być rozliczone przez jednostkę samorządu terytorialnego, która je utworzyła, a czynności dokonywane w ramach samorządu, tj. pomiędzy jej jednostkami, mają charakter wewnętrzny, neutralny z punktu widzenia podatku od towarów i usług.

Postanowienia TSUE oraz NSA przyczyniły się do rewolucyjnych zmian w wypracowanym przez lata, zupełnie odmiennym systemie rozliczania podatku od towarów i usług przez jednostki samorządu terytorialnego, który polegał na tym, że zarówno samorządowe jednostki budżetowe, jak i zakłady budżetowe gdy wykonywały czynności opodatkowane podatkiem od towarów i usług, były zarejestrowane jako odrębni podatnicy tego podatku. Stanowisko takie prezentowane i akceptowane było zarówno $\mathrm{w}$ indywidualnych interpretacjach podatkowych, jak i orzecznictwie sądowo-administracyjnym. Co jednak sprzeczne było z prawem UE w tym zakresie, w jakim zostało uniemożliwione jednostkom samorządu terytorialnego skorzystanie z prawa do odliczenia podatku od towarów i usług w takim stopniu, w jakim mogłoby to nastąpić, gdyby od początku przyjęto prawidłową interpretację przepisów ${ }^{42}$.

Konsekwencją wyroku TSUE nr C-276/14 oraz uchwały NSA z dnia 24 czerwca 2013r., sygn. akt I FPS 1/13, jest konieczność wdrożenia przez Ministerstwo Finansów systemowych rozwiązań w zakresie scentralizowanego modelu rozliczeń podatku od towarów i usług w gminach, powiatach i województwach i zapewnienia jednostkom tym odpowiednich instrumentów prawnych wspomagających proces centralizacji w wymiarze formalno- prawnym, jak i minimalizujących uciążliwości z tym związane.

42 Opinia z 18 marca 2016 r. o projekcie ustawy o zasadach rozliczeń w podatku od towarów i ustug oraz dokonywania zwrotu środków europejskich przez jednostki samorzadu terytorialnego oraz o zmianie ustawy o finansach publicznych, Rada Legislacyjna przy Prezesie Rady Ministrów, http://radalegislacyjna. gov.pl/dokumenty/opinia-z-18-marca-2016-r-o-projekcie-ustawy-o-zasadach-rozliczen-w-podatku-od-towarow-i (dostęp: 24.05.2016 r.). 
W celu wykonania wyroku TSUE nr C-276/14 oraz uporządkowania stanu prawnego Ministerstwo Finansów w dniu 18 stycznia 2016 r. opublikowało projekt ustawy o zasadach rozliczeń w podatku od towarów i usług oraz dokonywania zwrotu środków europejskich przez jednostki samorządu terytorialnego oraz o zmianie ustawy o finansach publicznych, który został przekazany do zaopiniowania przez Radę Legislacyjną przy Prezesie Rady Ministrów ${ }^{43}$. W dniu 5 kwietnia 2016 r. wprowadzono zmiany do projektu ustawy i dokonano także zmiany jej nazwy w brzmieniu ,ustawa o zasadach rozliczeń w podatku od towarów i usług oraz dokonywania zwrotu środków pochodzących z budżetu Unii Europejskiej lub od państw członkowskich EFTA a także ze środków publicznych, przeznaczonych na realizację projektów przez jednostki samorządu terytorialnego"44. Regulacja ta ma nowelizować ustawę o podatku dochodowym od osób prawnych oraz ustawę o finansach publicznych. Projektowana ustawa określa szczególne zasady dokonywania przez jednostki samorządu terytorialnego rozliczeń w podatku od towarów i usług w procesie przechodzenia na scentralizowany model rozliczenia tego podatku.

Zakres jej regulacji obejmuje ostateczny termin na dokonanie centralizacji rozliczeń podatku od towarów i usług, upływający w dniu 31 grudnia 2016 r.; zasady i terminy korekty rozliczeń podatku; zasady i terminy ewidencjonowania obrotu przy pomocy posiadanych kas rejestrujących oraz dokonywanie zwrotów środków publicznych przeznaczonych na realizację projektów finansowanych z udziałem środków pochodzących z budżetu Unii Europejskiej lub od państw członkowskich EFTA, a także ze środków publicznych, przeznaczonych na realizację projektów przez jednostki samorządu terytorialnego.

Początkowo planowano wprowadzić scentralizowany model rozliczenia podatku od towarów i usług w połowie 2016 r., ${ }^{45}$ jednak Minister Finansów, mając na uwadze liczne postulaty podnoszone przez przedstawicieli środowiska samorządowego dotyczące terminu obowiązkowej „centralizacji” rozliczeń w samorządach, przychylił się do zgłaszanych żądań i postanowił przesunąć ten termin z połowy 2016 r. na 1 stycznia $2017 \mathrm{r}^{46}$.

43 Projekt, https://legislacja.rcl.gov.pl/projekt/12281103 (dostęp: 24.05 .2016 r.).

44 Projekt, http://legislacja.rcl.gov.pl/projekt/12281103/katalog/12332879\#12332879 (dostęp: 25.05.2016 r.).

45 Wyrok TSUE - Gmina Wroctaw przeciwko Ministrowi Finansów - Komunikaty - Ministerstwo Finansów, http://www.mf.gov.pl/ministerstwo-finansow/wiadomosci/komunikaty (dostęp: 25.05.2016 r.).

46 Przesunięcie terminu, ,centralizacji” rozliczeń w samorzqdach-Komunikaty-Ministerstwo Finansów, http://www.mf.gov.pl/ministerstwo-finansow/wiadomosci/komunikaty (dostęp: 25.05.2016 r.). 


\section{Implementacja scentralizowanego modelu rozliczenia podatku od towarów i usług - nowe zadania i obowiązki jednostek samorządu terytorialnego}

Przejście na nowy scentralizowany system rozliczania podatku od towarów i usług dla poszczególnych jednostek samorządu terytorialnego związany będzie z bardzo skomplikowanymi wyliczeniami, dużym nakładem pracy, zmianami organizacyjnymi oraz zwiększonym zaangażowaniem osób odpowiedzialnych za rozliczenia finansowo-księgowe.

Przystępując do tego procesu w pierwszej kolejności należy ustalić moment przejścia na nowy system rozliczeń, z uwzględnieniem niezbędnego czasu potrzebnego do wykonania wszystkich niezbędnych czynności związanych z opracowaniem i wdrożeniem stosownych procedur wewnętrznych.

Analiza stanu faktycznego powinna polegać na zebraniu informacji dotyczących dotychczasowych rozliczeń poszczególnych jednostek organizacyjnych w zakresie podatku od towarów i usług oraz wykonywanych czynności, z którymi wiąże się uzyskiwanie przychodów zarówno w odniesieniu do jednostek organizacyjnych mających status podatnika podatku od towarów i usług, jak i tych korzystających ze zwolnienia podmiotowego z uwagi na wysokość osiąganych obrotów. Ponadto ustalić należy na gruncie podatku od towarów i usług, jakiego rodzaju czynności wykonywane były przez poszczególne jednostki organizacyjne (opodatkowane, zwolnione, niepodlegające opodatkowaniu podatkiem od towarów i usług) i jaka była ich wartość w ujęciu rocznym ${ }^{47}$.

Konsolidowanie rozliczenia podatku od towarów i usług w jednostkach samorządu terytorialnego powinno opierać się także na: opracowaniu zasad, procedur i regulaminów wewnętrznych dotyczących między innymi sposobów dokumentowania sprzedaży; zasad prowadzenia cząstkowej ewidencji zakupów i sprzedaży, sposobów ich oznaczania i numeracji; zasad i terminów przekazywania przez jednostki organizacyjne danych niezbędnych do sporządzenia łącznego rozliczenia podatku od towarów i usług; wyznaczeniu osób odpowiedzialnych za prawidłowość rozliczeń w zakresie podatku od towarów i usług w jednostkach organizacyjnych gmin, powiatów i województw; sporządzeniu aneksów umów cywilnoprawnych o zmianie strony umowy i ewentualnie

47 Jak przejść na nowy system rozliczeń w VAT - Wspolnota.org.pl, http://www.wspolnota.org.pl/aktualnosci/aktualnosc/jak-przejsc-na-nowy-system-rozliczen-w-vat (dostęp: 26.05.2016 r.). 
o doliczeniu do pobieranej ceny podatku od towarów i usług; dokonaniu jednolitej kwalifikacji w podatku od towarów i usług czynności wykonywanych przez jednostki samorządu terytorialnego oraz jednostki organizacyjne, a także przeprowadzeniu niezbędnych aktualizacji i zmian rejestracyjnych we właściwych urzędach skarbowych.

Z uwagi na skalę przedsięwzięcia i złożoną materię konieczne będzie zapewnienie odpowiedniego wsparcia merytorycznego i przeszkolenie pracowników jednostek organizacyjnych, a także dostosowanie systemów informatycznych dla potrzeb skonsolidowanego modelu rozliczania podatku od towarów i usług.

Projektowane regulacje gwarantują jednostkom samorządu terytorialnego brak konieczności zwrotu środków w przypadku korzystania przez nie z programów finansowanych ze środków europejskich w takim zakresie w jakim wskutek wyroku TSUE nr C-276/14 nastąpiła zmiana kwalifikowalności wydatku związanego z zakupem towarów i usług pod warunkiem, że nie dokonano obniżenia kwoty podatku należnego o kwotę podatku naliczonego $^{48}$. W następstwie czego nie wystąpi konieczność zwrotu kwot podatku naliczonego, objętego finansowaniem tymi środkami z budżetu państwa. Rozpatrując to uregulowanie przez pryzmat przepisów ustawy z dnia 17 grudnia 2004 r. o odpowiedzialności za naruszenie dyscypliny finansów publicznych ${ }^{49}$, należy uznać, iż fakultatywność wyboru tego rozwiązania, w przypadku zaniechania, jest zagadnieniem dość kontrowersyjnym. Zgodnie bowiem $\mathrm{z}$ art. 5 ust.1pkt 2 naruszeniem dyscypliny finansów publicznych jest niepobranie lub niedochodzenie należności Skarbu Państwa, jednostki samorządu terytorialnego lub innej jednostki sektora finansów publicznych albo pobranie lub dochodzenie tej należności w wysokości niższej niż wynikająca z prawidłowego obliczenia.

48 Projekt ustawy o zasadach rozliczeń w podatku od towarów i usług oraz dokonywania zwrotu środków europejskich przez jednostki samorzadu terytorialnego oraz o zmianie ustawy o finansach publicznych. Poprzedni tytuł: Projekt ustawy o szczególnych zasadach... - Wykaz prac legislacyjnych i programowych Rady Ministrów, BIP Rady Ministrów i Kancelarii Prezesa Rady Ministrów, http://bip.kprm.gov.pl/kpr/form/r2186, Projekt-ustawy-o-szczegolnych-zasadach-zwrotu-przez-jednostki-samorzadu-terytori. html (dostęp 29.06.2016 r.).

49 Tekst jedn. Dz.U. z 2013 r., poz. 168. 


\section{Podsumowanie}

W obecnej chwili trudno ocenić skutki finansowe wyroku TSUE nr C-276/14 oraz wpływu na bieżące dochody jednostek samorządu terytorialnego projektowanych przez Ministerstwo Finansów zmian z uwagi na specyfikę działań tych jednostek. Mogą wystąpić przypadki, w których część jednostek samorządu terytorialnego może odnotować dodatkowe dochody w postaci zwiększonych zwrotów podatku od towarów i usług, inne natomiast mogą ponieść dodatkowe koszty wynikające ze zwrotu części środków europejskich, skutkujące zwiększonymi wpłatami podatku od towarów i usług.

\section{Literatura}

1. Bober J. i in., Narastajace dysfunkcje, zasadnicze dylematy, konieczne działania: raport o stanie samorzadności terytorialnej w Polsce, Uniwersytet Ekonomiczny w Krakowie, Małopolska Szkoła Administracji Publicznej, Kraków 2013.

2. Borodo A., Finanse publiczne Rzeczypospolitej Polskiej. Zagadnienia prawne, Wydawnictwo Branta, Bydgoszcz 2000.

3. Bukowski Z., Jędrzejewski T., Rączka P., Ustrój samorządu terytorialnego, TNOiK Dom Organizatora, Toruń 2011.

4. Byjoch K., Sulimierski J., Tarno J.P., Samorzad terytorialny po reformie ustrojowej państwa, Wydawnictwa Prawnicze PWN, Warszawa 2000.

5. Izdebski H., Kulesza M., Administracja publiczna: zagadnienia ogólne, Liber, Warszawa 1999.

6. Izdebski H., Kulesza M., Administracja publiczna: zagadnienia ogólne, Liber, Warszawa 2004.

7. Izdebski H., Samorząd terytorialny: podstawy ustroju i działalności, LexisNexis, Warszawa 2008.

8. Kisiel W., Komentarz do art. 2, [w:] K. Bandarzewski, P. Chmielnicki, Ustawa o samorzadzie gminnym. Komentarz, LexisNexis, Warszawa 2013.

9. Nowacka E., Samorzą terytorialny w ustroju państwowym, LexisNexis, Warszawa 2003.

10. Ofiarski Z., Prawo finansowe, C.H. Beck, Warszawa 2010.

11. Owsiak S., Finanse publiczne: teoria i praktyka, PWN, Warszawa 2001.

12. Zubrzycki J., Leksykon VAT 2014, t. 1, Unimex, Wrocław 2014.

Marzanna Brylew

Urząd Skarbowy w Chełmnie 